\title{
Effects of Varying Tobacco Rod Circumference on Cigarette Combustion: An Experimental Investigation *
}

\author{
by \\ Nan Deng ${ }^{1}$, Yalin Wang ${ }^{1}$, Xiaomeng Cui ${ }^{2}$, Wenkang Zhao ${ }^{1}$, Qiaoling Li $^{3}$, \\ Chuan Liu ${ }^{4}$, Le Wang ${ }^{1}$, Xingyi Jiang ${ }^{5}$, Hexiang Chen ${ }^{3}$, and Bin $\mathrm{Li}^{l}$ \\ Zhengzhou Tobacco Research Institute of CNTC, Zhengzhou 450001, Henan, China \\ China Tobacco Zhejiang Industrial Co. Ltd., Hangzhou 310008, Zhejiang, China \\ China Tobacco Fujian Industrial Co. Ltd., Xiamen 361022, Fujian, China \\ Group Research \& Development, British American Tobacco, Southampton SO15 8TL, UK \\ 5 China National Tobacco Quality Supervision and Test Center, Zhengzhou 450001, Henan, China
}

\section{SUMMARY}

To study the effects of tobacco rod circumference on cigarette combustion status, cigarettes were made with three different circumferences of $24 \mathrm{~mm}, 20 \mathrm{~mm}, 17 \mathrm{~mm}$ and otherwise identical construction. Their combustion characteristics, including combustion coal volume, characteristic temperature distribution, heating rate, instantaneous burn rate, and yields of selected mainstream smoke chemicals, were systematically measured. The results indicated that the cigarettes with the lowest circumference of $17 \mathrm{~mm}$ showed higher combustion temperatures with a smaller coal volume. The maximum instantaneous burn rate was distinctly different for the three cigarettes, from $1.84 \mathrm{~mm} / \mathrm{s}$ to $2.48 \mathrm{~mm} / \mathrm{s}$, when their circumference was reduced from $24 \mathrm{~mm}$ to $17 \mathrm{~mm}$. The tobacco mass consumption per puff showed a negative trend when the circumference decreased. The majority of the chemical compounds (16 of 21) measured in mainstream smoke decreased when the circumference was reduced, except for formaldehyde, while the yields of the chemical compounds produced per weight of cut tobacco, consumed during puffing, showed an obverse trend. [Beitr. Tabakforsch. Int. 28 (2019) 286-296]

KEY WORDS: Cigarette, combustion, circumference

\section{ZUSAMMENFASSUNG}

Um die Auswirkungen des Umfangs eines Tabakstrangs auf die Zigarettenverbrennung zu untersuchen, wurden Zigaretten mit drei verschiedenen Umfängen von $24 \mathrm{~mm}$, $20 \mathrm{~mm}$ bzw. $17 \mathrm{~mm}$ mit ansonsten identischem Aufbau hergestellt. Ihre Verbrennungseigenschaften wurden systematisch gemessen, darunter das Volumen der Verbrennungskohle, charakteristische Temperaturverteilung, Erhitzungsrate, momentane Verbrennungsrate und die Ausbeute ausgewählter chemischer Verbindungen aus dem Hauptstromrauch. Die Ergebnisse zeigten, dass die Zigaretten mit dem geringsten Umfang von $17 \mathrm{~mm}$ höhere Verbrennungstemperaturen bei geringerem Kohlevolumen aufwiesen. Die maximale momentane Verbrennungsrate unterschied sich bei den drei Zigaretten deutlich und reichte von $1,84 \mathrm{~mm} / \mathrm{s}$ bis $2,48 \mathrm{~mm} / \mathrm{s}$ bei abnehmenden Umfängen von $24 \mathrm{~mm}$ bis $17 \mathrm{~mm}$. Der Verbrauch von Tabakmasse pro Zug zeigte bei abnehmendem Umfang einen negativen Trend. Mit Ausnahme von Formaldehyd nahm die Mehrzahl der im Hauptstromrauch gemessenen chemischen Verbindungen (16 von 21) ab, wenn der Umfang reduziert wurde, während die Ausbeuten der chemischen Verbindungen pro Gewicht des beim Ziehen verbrauchten Schnitttabaks einen entgegengesetzten Trend aufwiesen. [Beitr. Tabakforsch. Int. 28 (2019) 286-296] 


\section{RESUME}

Dans le but d'étudier les effets de la circonférence du boudin de tabac sur l'état de combustion de la cigarette, des cigarettes furent produites en trois circonférences différentes, à savoir respectivement $24 \mathrm{~mm}, 20 \mathrm{~mm}$ et $17 \mathrm{~mm}$ et suivant un conception sinon identique. Leurs caractéristiques de combustion furent systématiquement mesurées, parmi lesquelles le volume du charbon de combustion, les distributions de températures caractéristiques, la vitesse d'élévation en température, la vitesse de combustion instantanée et les rendements d'une sélection de produits chimiques présents dans la fumée principale. Les résultats indiquèrent que les cigarettes dont la circonférence était la plus étroite $(17 \mathrm{~mm})$ affichaient des températures de combustion plus élevées pour un moindre volume de charbon. La vitesse maximale de combustion instantanée fut clairement distincte pour chacune des trois cigarettes, allant de $1,84 \mathrm{~mm} / \mathrm{s}$ à $2,48 \mathrm{~mm} / \mathrm{s}$ lorsque la circonférence était réduite de $24 \mathrm{~mm}$ à $17 \mathrm{~mm}$. La consommation de masse de tabac par bouffée afficha une tendance négative en cas de diminution de la circonférence. A l'exception du formaldéhyde, la majorité des composés chimiques (16 sur 21) mesurés dans la fumée principale reculèrent en cas de rétrécissement de la circonférence alors que les rendements des composés chimiques générés par unité de poids de tabac haché consommé durant le fumage suivirent la tendance inverse. [Beitr. Tabakforsch. Int. 28 (2019) 286-296]

\section{INTRODUCTION}

Many physical properties of cigarettes, including cut tobacco size, cigarette paper permeability and cigarette filter ventilation levels, are known to significantly change combustion during smoking. In addition to changing the burning status, these properties can also influence ignition propensity, the smoke formation process, smoke aerosol and particle size, and chemicals produced in both mainstream and sidestream smoke (1). Among the cigarette design specifications, the tobacco rod circumference is one of the variables that can change. Cigarettes with reduced circumference have been marketed for more than 60 years, and are becoming increasingly popular in some countries for product differentiation. Compared with King Size cigarettes, Slim cigarettes not only show a distinctive appearance, but many thermophysical and thermochemical properties are also modified as published by MCADAM et al. (1). Changing the circumference of a cigarette mainly affects the tobacco weight per unit length of the tobacco rod, furthermore the draw resistance will also change, which results in a modification of the filter ventilation. Reducing cigarette rod circumference will result in a decrease of the tobacco weight per unit rod length, which will in turn increase the linear burn rate and decrease the mass burn rate during both puffing and smoldering periods $(2,3)$, for otherwise equal cigarette constructions. Therefore, reducing cigarette circumference will decrease the static burn time and the puff count under machine-smoking conditions. In addition, draw resistance is inversely proportional to the cross-sectional area of the tobacco rod at a constant volumetric flow (4).
In terms of thermochemical properties, previous research has shown that the cigarette dimensions may affect the smoke formation and aerosol transport processes which in turn could affect the yields of both mainstream and sidestream smoke (5). The proportion of most smoke components relative to total particulate matter (TPM) tends to decrease linearly with cigarette circumference except for some aldehydes, especially formaldehyde, which increases relatively to nicotine-free dry particulate matter (NFDPM) and nicotine. This may partly be attributed to a more oxidative burning environment although this has not been experimentally confirmed $(1,6)$. In some studies, reducing the tobacco rod circumferences is combined with other toxicant reduction technologies in order to achieve an overall toxicant reduction objective (7-10).

Cigarette smoke is produced when the tobacco is burned, the temperature of the cigarette burning coal can exceed $950{ }^{\circ} \mathrm{C}$ during cigarette combustion. Many physical and chemical processes occur inside the combustion zone of a cigarette. The combustion zone of the cigarette can be divided into a pyrolysis/distillation region and a combustion region (11). The vast majority of smoke products are formed in the pyrolysis/distillation region $(5,11)$.

Using cigarettes with equal packing density and the same puffing parameters, DEBARDELEBEN et al. (12) measured decreases in TPM, NFDPM, nicotine and carbon monoxide as the cigarette circumference decreased from $26.0 \mathrm{~mm}$ to $23.0 \mathrm{~mm}$. YАМАМОто et al. (13) confirmed these results for NFDPM and nicotine using filtered cigarettes with circumferences ranging from $25.8 \mathrm{~mm}$ to $21.1 \mathrm{~mm}$ which were made with blended tobacco and all-Virginia tobacco. In a follow-up study (14), they found that the yields of carbon monoxide, carbon dioxide, nitrogen dioxide, vapor phase acetaldehyde and benzo $[a]$ pyrene decreased at different rates when reducing cigarette circumference. SIU et al. (15) analyzed the smoke chemistry of commercial cigarettes with $17 \mathrm{~mm}$ circumference in the Canadian market, and found that the yields of carbon monoxide, carbonyls, volatiles and aromatic amines were significantly lower for the Super Slim cigarettes, but their yields of formaldehyde and ammonia were significantly higher. When the temperature of a burning cigarette was changed, the yields of cigarette smoke were inevitably affected. These changes in smoke yields were partly attributed to the changes in cigarette combustion.

To characterize the combustion of cigarettes, extensive research has been carried out by applying multidisciplinary experimental, theoretical and computational modeling techniques. Early studies have characterized the combustion processes of cigarettes $(11,16-19)$. Recently, our group has developed a special test module composed of eight thermocouples for a more accurate characterisation of the combustion or pyrolysis conditions of the burning coal (20). Based on this technique, the temperature distribution of the combustion coal under different puffing conditions, levels of filter ventilation and other cigarette design parameters have been investigated $(21,22)$. To our knowledge, there has been no systematic study in the literature on modern cigarettes which examined the effects of cigarette circumference on the combustion dynamics and on smoke yields.

In this study, we aimed to investigate the specific effects of 
Table 1. Measured physical parameters of the three cigarette designs.

\begin{tabular}{l|c|c|c|c|c|c}
\hline $\begin{array}{l}\text { Circumference } \\
(\mathrm{mm})\end{array}$ & $\begin{array}{c}\text { Cigarette paper } \\
\text { permeability }(\mathrm{CU})\end{array}$ & $\begin{array}{c}\text { Grammage } \\
\left(\mathrm{g} / \mathrm{m}^{2}\right)\end{array}$ & $\begin{array}{c}\text { Combustion modifier } \\
\text { content }(\mathrm{mg} / \mathrm{g})\end{array}$ & $\begin{array}{c}\text { Cigarette length } \\
(\text { tobacco rod }+ \text { filter })(\mathrm{mm})\end{array}$ & $\begin{array}{c}\text { Rod ventilation } \\
(\%)\end{array}$ & $\begin{array}{c}\text { Draw resistance } \\
(\mathrm{Pa})\end{array}$ \\
\hline 24 & 56.9 & 29.7 & 13.4 & $84(57+27)$ & $51.88(\mathrm{sealed})$ & 1005 \\
20 & 55.5 & 29.3 & 11.6 & $97(67+30)$ & $52.03($ sealed $)$ & 1103 \\
17 & 56.3 & 30.0 & 12.5 & $97(67+30)$ & $15.80($ sealed $)$ & 1240 \\
\hline
\end{tabular}

certain cigarette circumferences $(24 \mathrm{~mm}, 20 \mathrm{~mm}$ and $17 \mathrm{~mm}$ ) on the burning status, with all other design parameters being kept unchanged. This was achieved by comparing their combustion coal characteristics, including combustion volume $\left(V_{0}\right.$, cumulative coal volume above $\left.200^{\circ} \mathrm{C}\right)$, characteristic temperature $\left(T_{0.5}\right.$, representing a temperature threshold when $V$ reaches $50 \%$ of $V_{0}$ ), maximum temperature $\left(T_{\max }\right.$, maximum temperature of the burning coal), temperature range $\left(T_{0.1}-T_{0.9}\right.$ gave an indicator of the temperature difference when $V / V_{0}$ reached $10 \%$ and $90 \%$ ), as well as heating rate, and instantaneous combustion rate. Several key classes of chemical components in the mainstream smoke were also measured accordingly. This study provides a deep insight into the mechanisms of the cigarette combustion process and on the impact of varying tobacco rod circumference.

\section{EXPERIMENTAL}

\subsection{Cigarette samples}

Three cigarette designs were tested in this study. They were provided by China Tobacco Fujian Industrial Co. Ltd. (Xiamen, Fujian, China). They used an identical flue-cured tobacco blend with $100 \%$ cut lamina for all the cigarettes. They were identical in regard to cigarette paper, tobacco composition and tobacco density while they differed with respect to their length and rod ventilation, which led to different draw resistances. The physical parameters of the cigarettes are shown in Table 1. The filter ventilation of the samples was sealed before testing to make sure the conditions regarding filter ventilation were equal in all test designs. The samples were conditioned at $22{ }^{\circ} \mathrm{C}$ and $60 \%$ relative humidity for at least $48 \mathrm{~h}$. The cigarettes used in the experiments were further selected based on their average weight of $\pm 5 \mathrm{mg}$, and an average pressure drop of $\pm 50 \mathrm{~Pa}$ with the aim to reduce testing variability.

\subsection{Combustion temperature measurement}

The cigarette combustion temperature measurement system used in this study has been described before (20-22). To provide a brief description: the system consisted of a thermocouple insertion kit, a single-port smoking machine and a high-speed analogue-to-digital converter. In the thermocouple insertion kit, a test cigarette was first loaded into a holder. Eight thermocouples accommodated in a single integrated module could be inserted in their predefined positions ("+") along the cigarette rod. Five insertion depths $(0, \mathrm{~d} / 8,2 \mathrm{~d} / 8,3 \mathrm{~d} / 8,4 \mathrm{~d} / 8)$ were selected in cross section, as shown in Figure 1.

Letter " $d$ " represents the diameter of the cigarette. To seal the paper around the thermocouple insertions, a small amount of starch-based paper glue was applied manually. After that, the thermocouple kit could be fixed with the holder, which was then connected to a single-port smoking machine. An analogue-to-digital converter (Omega, Stamford, Connecticut, USA) captured the thermocouple outputs at $10 \mathrm{~Hz}$. Because of the vertical axial symmetry of the tobacco rod (the tobacco rods were horizontally positioned), only half of the cross section was measured. Four replicate measurements were performed for each cigarette design (20 cigarettes) and the replicate data sets were averaged for experimental relative standard deviation (RSD) reduction. The system output also contained the times, locations and temperature values, which allowed for reconstruction of either 1-D to 2-D temperature contour maps. A modified Rosin-Rammler (R-R) distribution equation, which has been widely used for modeling irregularly shaped particles (e.g., coal particles) and their mass distribution, was used here for modeling the temperature distribution (20).

The $6^{\text {th }}$ thermocouple, labeled from left to right, played a key role in providing a reference thermocouple to improve overall measurement reproducibility. As the approaching smoldering coal raised its temperature to a pre-defined temperature value (Table 2), the smoking machine was triggered to take a defined puff. The pre-defined temperature value was determined by two thermocouples in adjacent axial positions $\left(5^{\text {th }}\right.$ and $\left.6^{\text {th }}\right)$ at five insertion depths. Specifically, after the cigarette was lit and began to smolder, the temperatures of the $5^{\text {th }}$ and $6^{\text {th }}$ thermocouples at radial center (0) were recorded as $T_{5}^{4}$ and $T_{6}^{4}$, respectively. Then keeping the $5^{\text {th }}$ thermocouple still, the $6^{\text {th }}$ thermocouple was moved to $1 \mathrm{~d} / 8$ position. When the temperature of the $5^{\text {th }}$ thermocouple reached $T_{5}^{4}$, the temperature of the $6^{\text {th }}$ thermocouple was recorded as $T_{6}^{3}$. The remaining radial positions $(2 \mathrm{~d} / 8,3 / 8,4 \mathrm{~d} / 8)$ could be carried out in the same manner, thus $T_{6}^{2}, T_{6}{ }^{1}, T_{6}{ }^{0}$ were obtained, as shown in Table 2 .

\subsection{Temperature representation}

In order to describe the cigarette burning process in detail, several temperature parameters were defined and used in our previous studies (20-22). During the cycle of smoldering and puffing, the coal volume $(V)$ is experiencing constant fluctuations as a result of the forced air flow. Cumulative coal volume is given according to the modified R-R distribution equation. $T_{\max }$ describes the maximum temperature of the burning coal. $V(T)$ is the volume in the cigarette with a temperature $>T . V_{0}$ is the volume at $T$ $=200{ }^{\circ} \mathrm{C}$, i.e., $V_{0}=V\left(200{ }^{\circ} \mathrm{C}\right) . T_{x}$ is the temperature for which $V\left(T_{x}\right) / V_{0}=x$ is applicable from high to low temperature in the burning coal. $T_{0.5}$ is a characteristic temperature, 


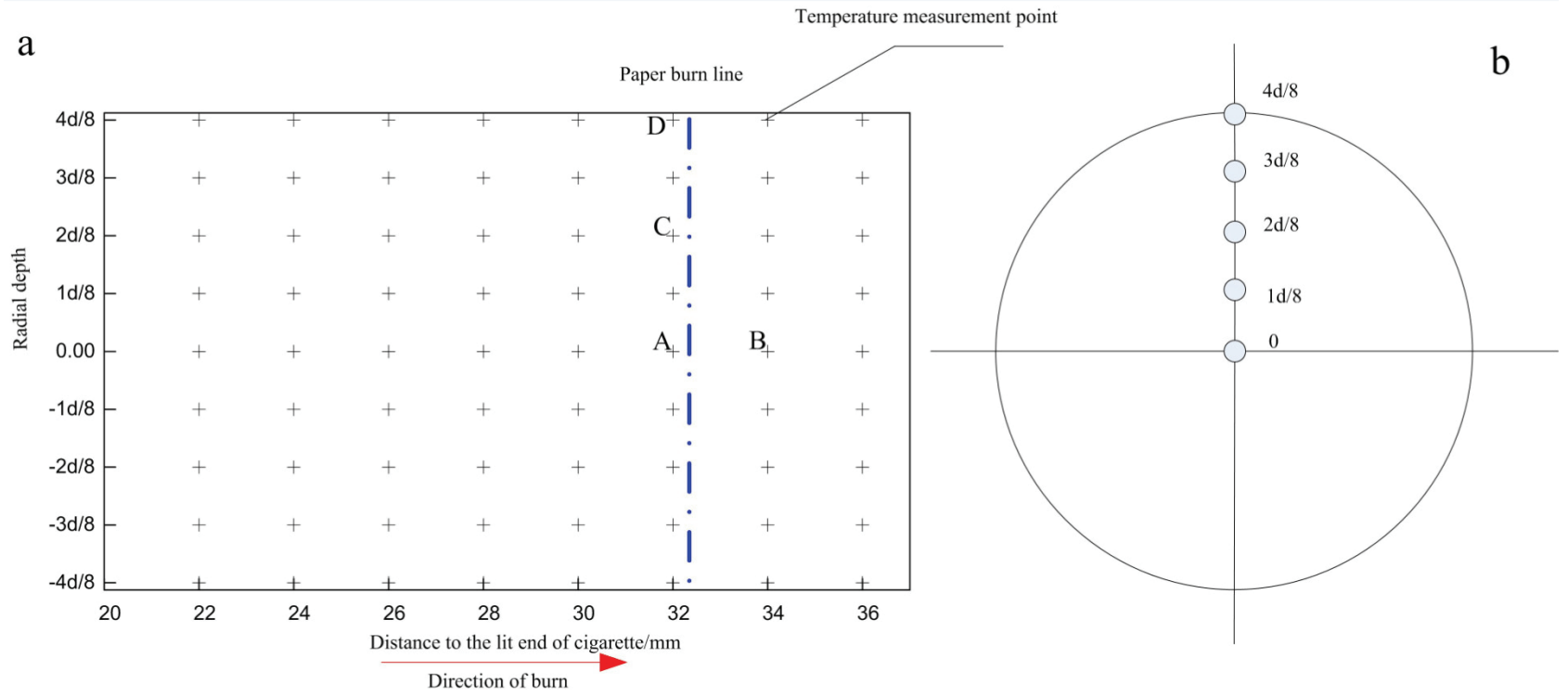

Figure 1. The thermocouple position grids along the rod (a) and inside its cross-section (b). The blue dotted line is the burning line, A, B, C, D were the selected typical positions.

Table 2. Pre-defined temperature values of three cigarette designs triggering the smoking machine into puffing.

\begin{tabular}{l|c|c|c|c|c}
\hline $\begin{array}{l}\text { Circumference } \\
(\mathrm{mm})\end{array}$ & $\begin{array}{c}T_{6}^{4} \\
\left({ }^{\circ} \mathrm{C}\right)\end{array}$ & $\begin{array}{c}T_{6}^{3} \\
\left({ }^{\circ} \mathrm{C}\right)\end{array}$ & $\begin{array}{c}T_{6}^{2} \\
\left({ }^{\circ} \mathrm{C}\right)\end{array}$ & $\begin{array}{c}T_{6}^{1} \\
\left({ }^{\circ} \mathrm{C}\right)\end{array}$ & $\begin{array}{c}T_{6}^{0} \\
\left({ }^{\circ} \mathrm{C}\right)\end{array}$ \\
\hline 24 & 250 & 325 & 400 & 440 & 480 \\
20 & 195 & 275 & 305 & 400 & 480 \\
17 & 180 & 220 & 305 & 400 & 480 \\
\hline
\end{tabular}

representing a temperature threshold when $V$ reaches $50 \%$ of $V_{0} . T_{0.1}-T_{0.9}$ is a temperature range, which gives an indicator of the temperature distribution width in the burning coal. The higher this value, the wider the temperature distribution would be. By plotting these distribution parameters as a function of the puffing time, a more detailed way was developed for describing the cigarette burning process. These distribution parameters can directly provide a combination of coal volume and temperature range information, which could help to extract mechanistic details.

The linear instantaneous burn rate of the tobacco rod was measured by the movement of $T_{0.5}$ (23). Briefly, the temperature of the $M_{1}$ point, located at the center axial, was the characteristic temperature $T_{0.5}\left(M_{1}\right)$ at $t_{1}$. Then there must have been a $N_{1}$ point at the center axial whose temperature would reach $T_{0.5}\left(N_{1}\right)$ at another time $\left(t_{2}\right)$. The linear instantaneous rate was calculated by the distance between $M_{1}$ and $N_{1}$, and the time interval from $t_{1}$ to $t_{2}$. Except $M_{1}$ and $N_{1}$, there were numerous positions parallel to the center axial, which would also reach $T_{0.5}$ at $t_{1}$ and $t_{2}$ moment. Therefore, the linear instantaneous burn rate was calculated based on the average data during every $0.1 \mathrm{~s}$, and could be calculated based on equation [1], In which $\Delta L$ is the distance between two positions ( $M$ and $N$ ).

$$
v=\frac{\Delta L_{\left(M_{1}-N_{1}\right)}+\Delta L_{\left(M_{2}-N_{2}\right)}+\ldots \Delta L_{\left(M_{n}-N_{n}\right)}}{n\left(t_{2}-t_{1}\right)}
$$

\subsection{Chemical analysis of mainstream smoke}

Total particulate matter and NFDPM were determined according to ISO 4387:2000. Nicotine and water were determined by ISO 10315:2000 and ISO 10362-2, respectively. $\mathrm{CO}$ was trapped and analyzed in accordance with ISO 8454:1995 (30-33). HCN, phenol, $\mathrm{NH}_{3}, \mathrm{~B}[a] \mathrm{P}$ and TSNAs were analyzed separately, based on CORESTA Recommended Methods, as were formaldehyde, acetaldehyde, acetone, acrolein, propionaldehyde, crotonaldehyde, 2-butanone and butyraldehyde. Cigarettes were smoked under ISO smoking regime ISO 3308:2012 (34) (2 s puff duration, $35 \mathrm{~mL}$ puff volume, once every $60 \mathrm{~s}$, under a bell-shaped puff profile).

\section{RESULTS AND DISCUSSION}

\subsection{Temperature distribution characteristics of combustion coal}

Figure 2 displays the temperature contours at three points in time during the 2-s puff: immediately before the puff $(0 \mathrm{~s})$, at the peak of the puff ( $1 \mathrm{~s}$ after the bell-shaped puff started), and at the end of the puff $(2 \mathrm{~s})$. Heating rate (dT/dt) contours are shown in Figure 3. During puffing the temperature as well as the heating rate of slimmer cigarettes was much higher, especially at the peak of the puffs. From $1 \mathrm{~s}$ to $2 \mathrm{~s}$, the heating rate of the $17 \mathrm{~mm}$-circumference cigarette changed rapidly compared with the other two cigarettes. This was mainly due to the fact that the same amount of air introduced into the cigarette had to cool a smaller amount of burning tobacco. In addition, when the same amount of air came into the cigarette, the reduced cross-sectional area would result in a higher gas flow velocity (24). The higher the gas flow velocity, the faster the heat would be taken away. 
$17 \mathrm{~mm}$
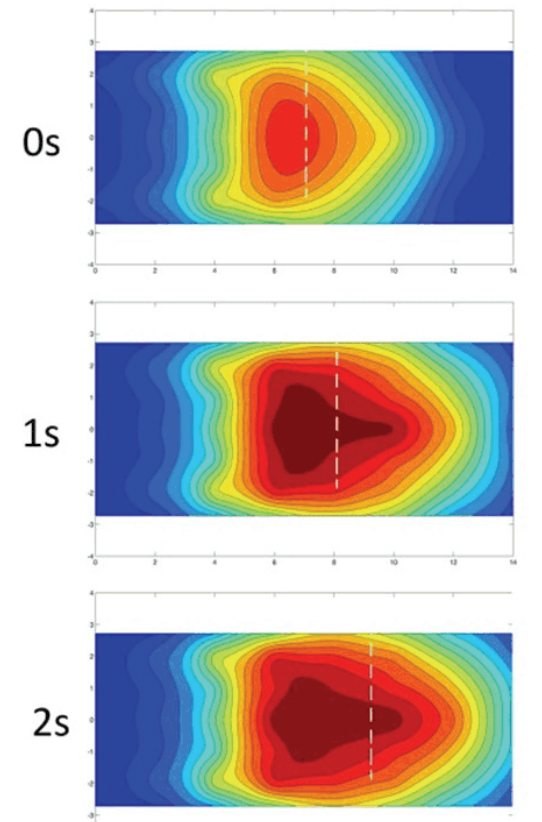

Figure 2. Temperature $(T)$ contours from cigarettes of a circumference of $17 \mathrm{~mm}, 20 \mathrm{~mm}, 24 \mathrm{~mm}$ at $0 \mathrm{~s}, 1 \mathrm{~s}, 2 \mathrm{~s}$ after the puff started. The burning direction was from left to right.
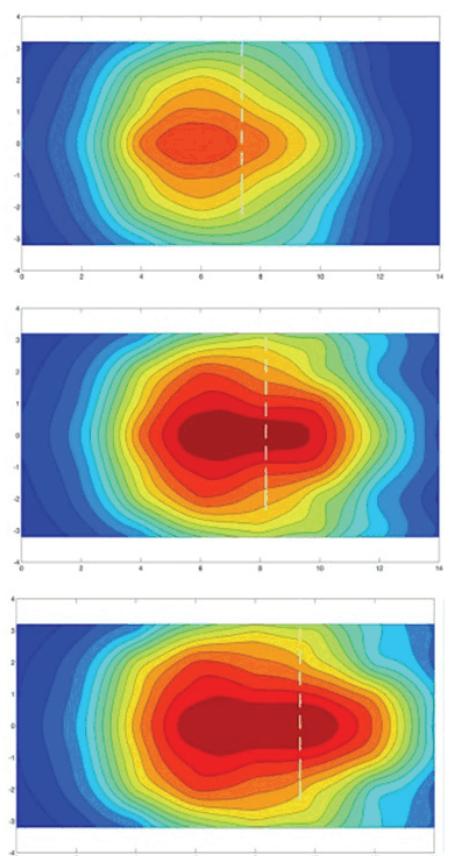

$24 \mathrm{~mm}$
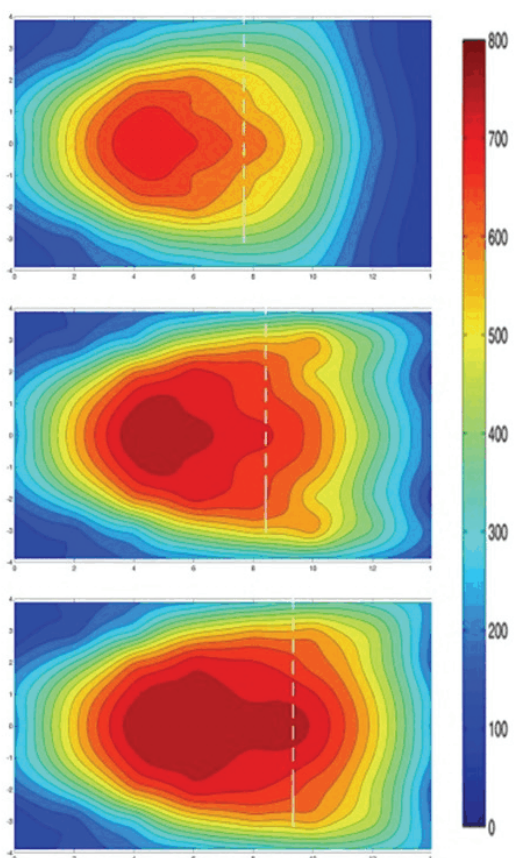

$17 \mathrm{~mm}$
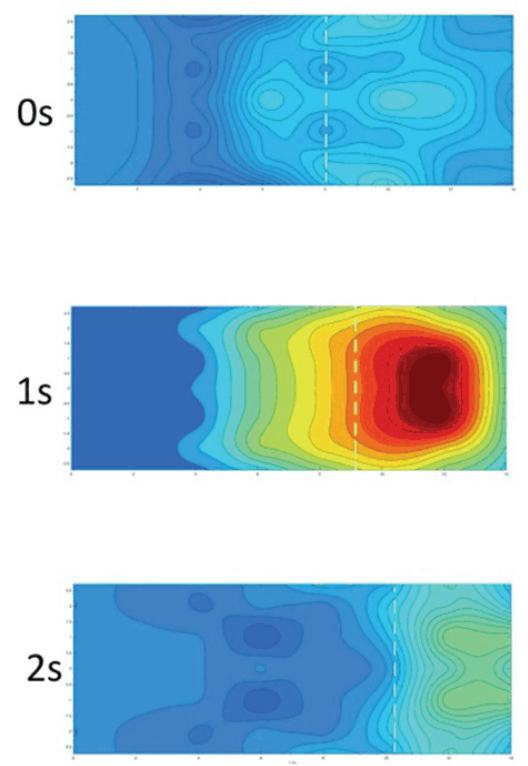

$20 \mathrm{~mm}$
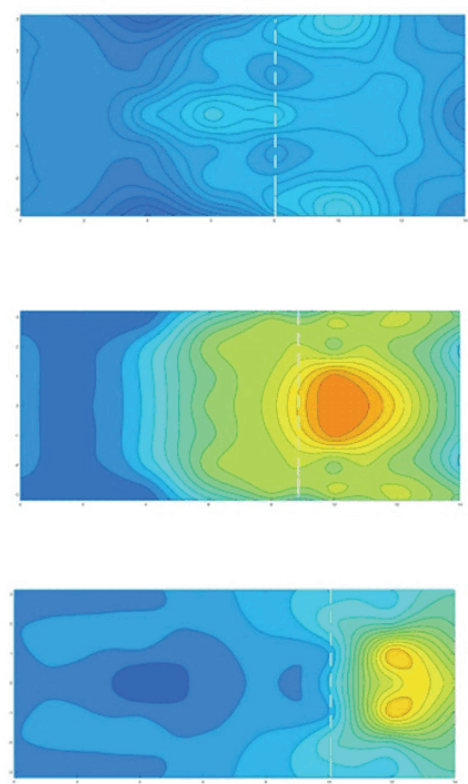

$24 \mathrm{~mm}$
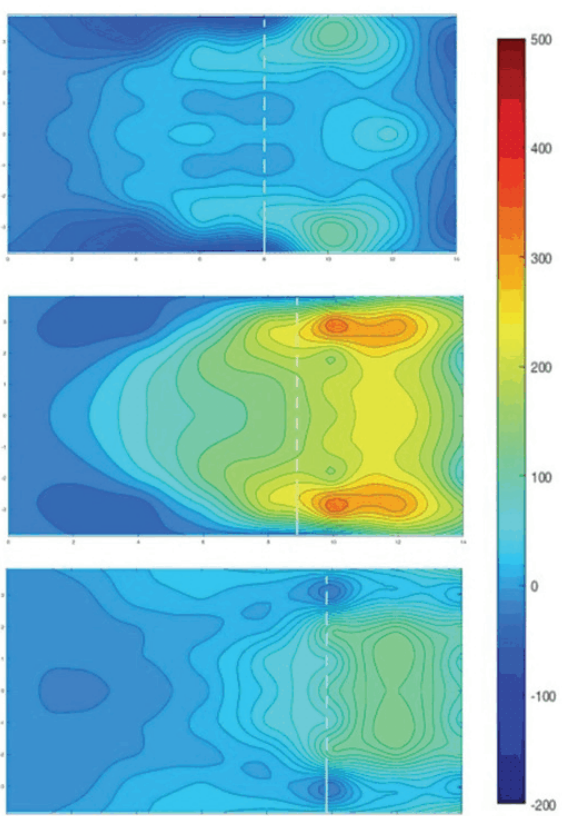

Figure 3. Heating rate $(d T / d t)$ contours from cigarettes of a circumference of $17 \mathrm{~mm}, 20 \mathrm{~mm}, 24 \mathrm{~mm}$ at $0 \mathrm{~s}, 1 \mathrm{~s}, 2 \mathrm{~s}$ after the puff started. The burning direction was from left to right.

The characteristic temperature parameters for the three test cigarettes are shown in Figure 4 (over time). The time from $-2 \mathrm{~s}$ to $0 \mathrm{~s}$ marks the smoldering prior to puffing. The puff took place from $0 \mathrm{~s}$ to $2 \mathrm{~s}$. During smoldering and puffing, the cigarettes with $24 \mathrm{~mm}$ circumference had the largest volume $V_{0}$ (maximum value was $577.4 \mathrm{~mm}^{3} \pm 23.4 \mathrm{~mm}^{3}$ ) of combustion coal. It is also worth noting that during smoldering, the maximum temperature $\left(T_{\max }\right)$ was higher for cigarettes with a larger circumference. However, during puffing, the maximum temperature was lower for cigarettes with a larger circumference. The $T_{\max }$ of $17 \mathrm{~mm}$ circumference reached $818.8^{\circ} \mathrm{C} \pm 17.6^{\circ} \mathrm{C}$ which was higher than the 
levels observed with the other two other circumferences $\left(796.8{ }^{\circ} \mathrm{C} \pm 15.5{ }^{\circ} \mathrm{C}\right.$ for the $20 \mathrm{~mm}$ circumference, $786.4{ }^{\circ} \mathrm{C} \pm 9.9{ }^{\circ} \mathrm{C}$ for the $24 \mathrm{~mm}$ circumference).

During the puffing process, the highest value of $T_{0.5}$ was $527.7^{\circ} \mathrm{C} \pm 8.1{ }^{\circ} \mathrm{C}$ for $17 \mathrm{~mm}$ circumference, $459.2^{\circ} \mathrm{C} \pm$ $15.5^{\circ} \mathrm{C}$ for $20 \mathrm{~mm}$ circumference, and $452.2{ }^{\circ} \mathrm{C} \pm 8.2{ }^{\circ} \mathrm{C}$ for $24 \mathrm{~mm}$ circumference. For $T_{0.1}-T_{0.9}$, the maximum was $519.6{ }^{\circ} \mathrm{C} \pm 11.9{ }^{\circ} \mathrm{C}, 451.7{ }^{\circ} \mathrm{C} \pm 10.9{ }^{\circ} \mathrm{C}, 492.0^{\circ} \mathrm{C} \pm$ $25.2^{\circ} \mathrm{C}$, respectively. Therefore, the characteristic temperature $\left(T_{0.5}\right)$ and the range of temperatures $\left(T_{0.1}-T_{0.9}\right)$ of the cigarettes with $17 \mathrm{~mm}$ circumference were much higher. As shown in Figure 4(c), $T_{0.5}$ showed a rapid change when the puffing was started. During the ongoing puffing process, the increased $T_{0.5}$ indicated that the ratio of high temperature volume became larger. Compared to cigarettes of $20 \mathrm{~mm}$ and $24 \mathrm{~mm}$ circumferences, cigarettes of $17 \mathrm{~mm}$ circumference showed higher $T_{0.5}$, demonstrating that there was a larger volume proportion of high temperature for this cigarette design. While the smaller coal volume in cigarettes of $17 \mathrm{~mm}$ circumference further illustrated that the higher temperatures $\left(>T_{0.5}\right)$, occurring in slimmer cigarettes, were more concentrated than in the cigarettes of $20 \mathrm{~mm}$ and $24 \mathrm{~mm}$ circumference. The range of $T_{0.1}-T_{0.9}$ for cigarettes of $17 \mathrm{~mm}$ circumference illustrated that the temperature between $T_{0.1}$ to $T_{0.9}$ was dispersed more widely in the combustion coal zone than in cigarettes of the other two designs. Beside the temperature and heating rate contours sketched in Figures 2 and 3, four representative positions A, B, C and D (Figure 1) were selected to illustrate the dynamic temperature variations inside the combustion coal. In this study, the sixth thermocouple was used to trigger the smoking machine to start puffing $(0 \mathrm{~s})$. Positions A, C, and D were located at the detection point of the sixth thermocouple with different radial spacings, on the left side of the paper burn line. Position B was located at the detection point of the seventh thermocouple, on the right side of the paper burn line. The temperatures and heating rates of these four points are shown in Figure 5. From four replicate measurings, the average standard deviation of temperature from $-2 \mathrm{~s}$ to $4 \mathrm{~s}$ was $21.3^{\circ} \mathrm{C}$ with a coefficient of variation of $5.05 \%$. The average standard deviation of heating rates before puffing $\left(10 \mathrm{~s}\right.$ in total) was $5.5^{\circ} \mathrm{C} / \mathrm{s}$.

At positions $\mathrm{A}$ and $\mathrm{B}$, both the temperature and the heating rate were highest for the cigarettes of $17 \mathrm{~mm}$ circumference and lowest for the cigarettes of $24 \mathrm{~mm}$ circumference. For position $\mathrm{C}$, which was located between the middle of the central axis and the cigarette surface, the cigarettes of $24 \mathrm{~mm}$ circumference had the highest temperature before puffing. When a puff started, the temperature of cigarettes of $17 \mathrm{~mm}$ circumference increased rapidly, therefore, it showed the highest heating rate. As position $\mathrm{D}$ was located on the surface of the cigarettes, the radiative heat loss might have been considerable, which resulted in a lower temperature. In addition, the temperature at this position was likely to be influenced by air convection around the cigarette.
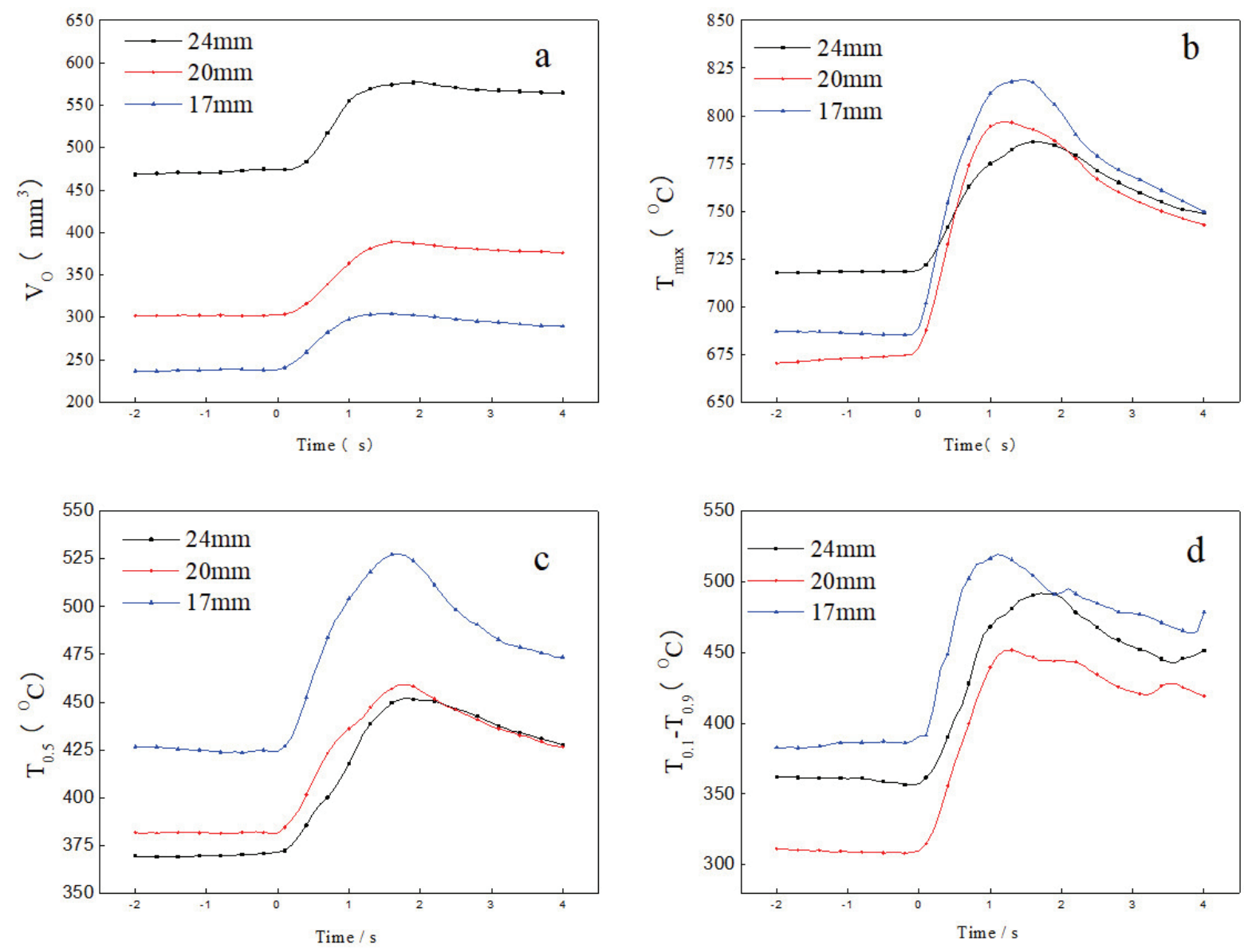

Figure 4. Temperature distributions during puffing measured in cigarettes of three different circumferences. 

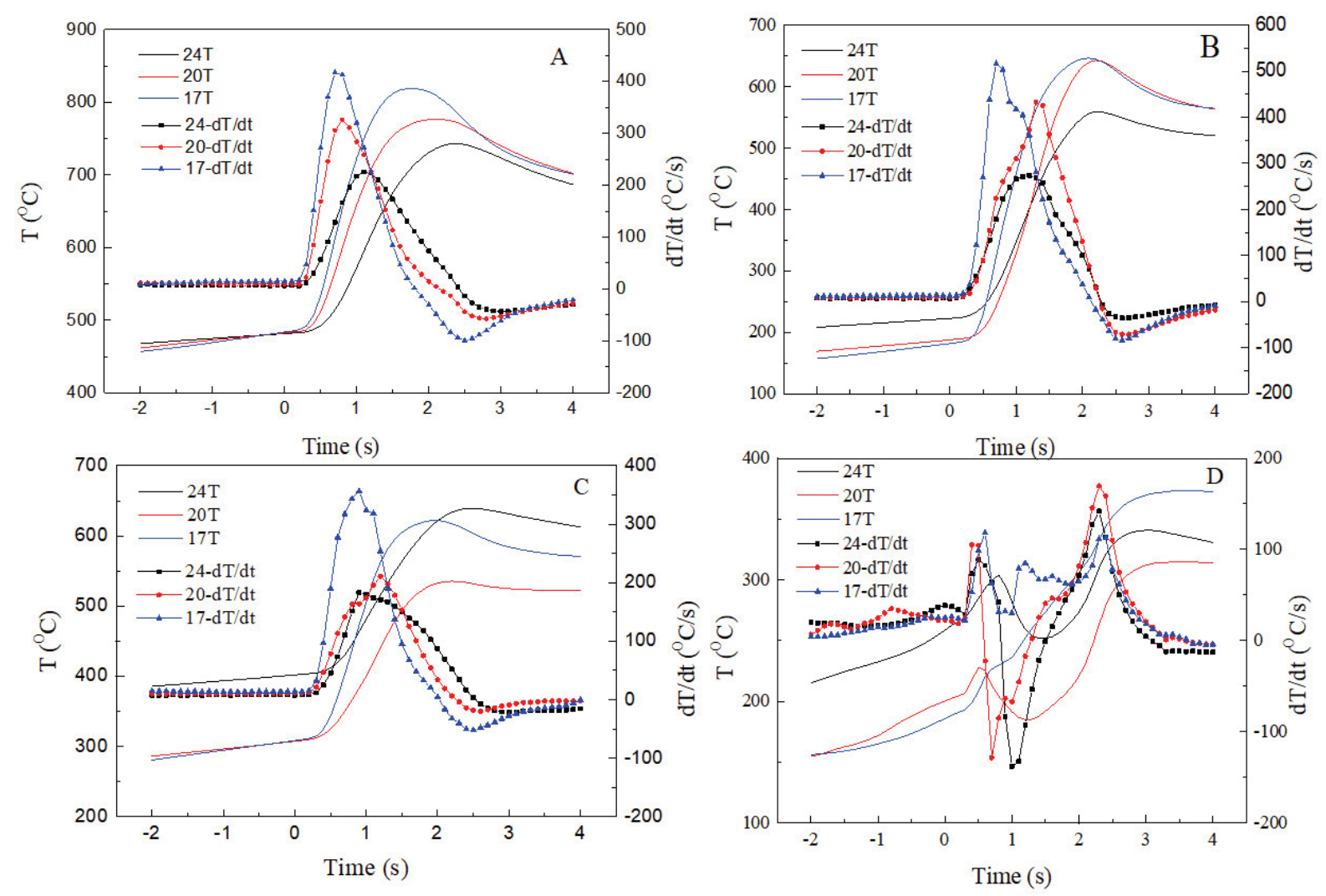

Figure 5. Temperature and heating rates for four selected positions in the burning cigarette.

\subsection{Instantaneous burn rate}

The linear burn rate is one of the main indicators of the speed of cigarette burn and influences the puff number, hence studies in the literature have focused on the static burn rate. However, during puffing, the dynamics of the combustion of the coal change rapidly. The shape of the combustion coal also changes quickly during puffing. To account for the dynamic nature of the combustion, $T_{0.5}$ was defined as a representative parameter to characterize the cigarette combustion coal by the movement of $T_{0.5}$ inside the combustion zone, this was achieved by temperature measurement and the R-R distribution model (20). As a result, the instantaneous burn rate could be characterized, no matter whether the cigarette was smoldering or during a puff.

Figure 6 shows the instantaneous linear burn rate (i-LBR) and the instantaneous mass burn rate (i-MBR) over time. The latter was calculated by multiplying i-LBR with the tobacco weight per unit length $(\mathrm{mg} / \mathrm{mm})$. The results show that the cigarettes of $17 \mathrm{~mm}$ circumference had the highest i-LBR, but the lowest i-MBR. And the distribution of i-LBR and i-MBR was visibly correlated to the bell-shaped puff profile (Figure 6) of the test cigarettes. Table 1 shows the detailed values on a puff basis. It was clear that the smoldering rate was low in relation to the puff-burn rate, and it decreased with the increase of cigarette circumference. Both, the linear and the mass burn rate increased quickly during puffing. The maximum i-LBRs were $1.84 \pm 0.09 \mathrm{~mm} / \mathrm{s}, 1.86 \pm 0.04 \mathrm{~mm} / \mathrm{s}, 2.48 \pm 0.09 \mathrm{~mm} / \mathrm{s}$ for the cigarettes with $24 \mathrm{~mm}, 20 \mathrm{~mm}$ and $17 \mathrm{~mm}$ circumfer- ence, respectively. On the other hand the maximum i-MBR decreased when cigarette diameters decreased. RESNIK et al. (25) have shown that the tobacco weight burnt is reduced when the cigarette circumference is reduced at equal packing density. Under the same puffing regimen, a Super Slim cigarette (with $17 \mathrm{~mm}$ circumference) displayed a higher burn rate and reduced tobacco consumption, which agrees with Table 3 . The distance of the paper burn line could be calculated by numerically integrating the instantaneous burn rate over the $2 \mathrm{~s}$ puff at time steps of $0.1 \mathrm{~s}$. As shown in Table 3, the distance the paper burn line moves during a puff was calculated based on the instantaneous burn rate. It becomes larger when the circumference is reduced from $24 \mathrm{~mm}$ to $17 \mathrm{~mm}$, which also agrees with the reduced puff numbers for Super Slim cigarettes $(26,27)$. In agreement with the burn rate, the tobacco volume consumed during one puff in cigarettes was calculated to be $94.06 \mathrm{~mm}^{3}, 70.42 \mathrm{~mm}^{3}, 54.7 \mathrm{~mm}^{3}$, respectively, for the cigarettes of $24 \mathrm{~mm}, 20 \mathrm{~mm}$, and $17 \mathrm{~mm}$ circumference.

\subsection{Chemical compounds in mainstream smoke}

More than 6,000 chemical compounds have been identified in the cigarette mainstream smoke (28), and at least 150 of these compounds are considered toxic. In this study, the influence of cigarette circumference on different classes of chemical compounds in mainstream smoke was measured under standard smoking conditions (ISO 3308). The smoke yields were analysed on a per-puff basis, on a per-NFDPM basis and on a per-weight-of-tobacco-burnt-during-puffing basis respectively. 

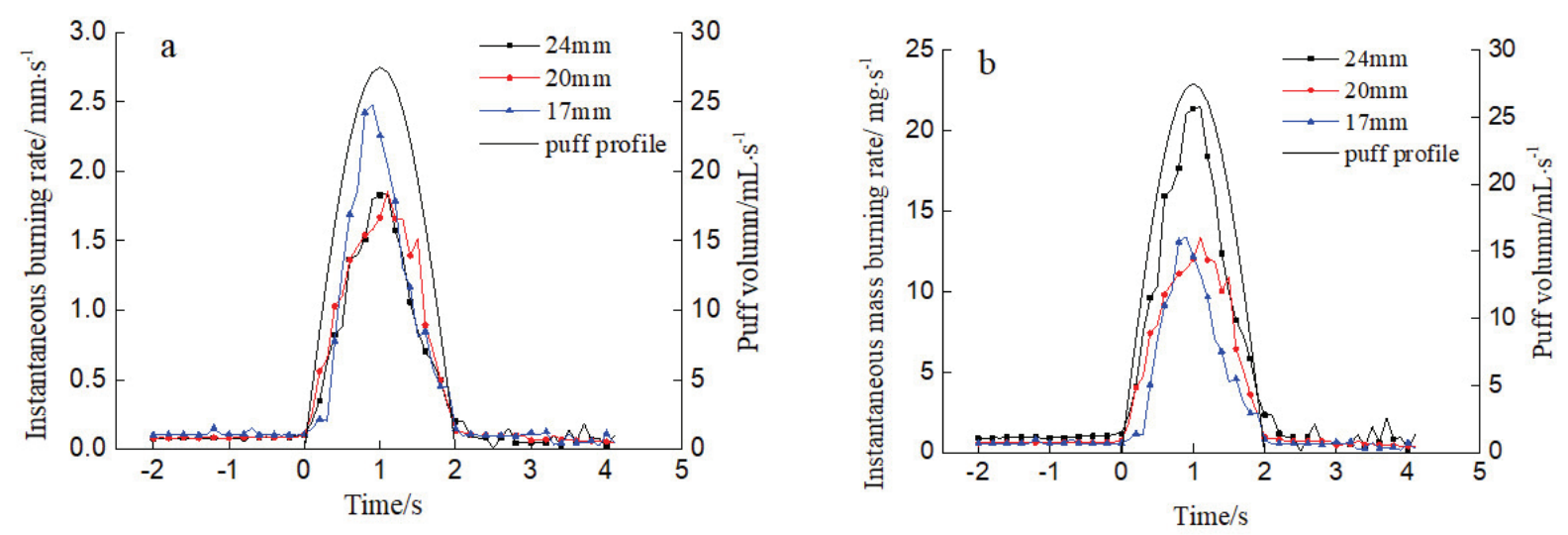

Figure 6. Instantaneous linear burn rate (a) and instantaneous mass burn rate (b) of cigarettes with different circumference.

Table 3. Different parameters of the cigarette burn rate for three cigarette circumferences.

\begin{tabular}{l|c|c|c|c|c}
\hline $\begin{array}{l}\text { Circumference } \\
(\mathrm{mm})\end{array}$ & $\begin{array}{c}\text { Average smoldering } \\
\text { rate }(\mathrm{mm} / \mathrm{s})\end{array}$ & $\begin{array}{c}\text { Average burn rate } \\
(\mathrm{mm} / \mathrm{s})\end{array}$ & $\begin{array}{c}\text { Maximum burn rate } \\
(\mathrm{mm} / \mathrm{s})\end{array}$ & $\begin{array}{c}\text { Distance of the burning line } \\
\text { moving per puff }(\mathrm{mm})\end{array}$ & $\begin{array}{c}\text { Cut tobacco consumption } \\
\text { per puff }(\mathrm{mg})\end{array}$ \\
\hline 24 & $0.08 \pm 0.01$ & $0.93 \pm 0.10$ & $1.84 \pm 0.09$ & $1.95 \pm 0.17$ & $23.29 \pm 1.87$ \\
20 & $0.09 \pm 0.01$ & $1.04 \pm 0.04$ & $1.86 \pm 0.04$ & $2.19 \pm 0.04$ & $15.80 \pm 0.56$ \\
17 & $0.11 \pm 0.02$ & $1.10 \pm 0.13$ & $2.48 \pm 0.09$ & $2.31 \pm 0.30$ & $12.44 \pm 1.65$ \\
\hline
\end{tabular}

\subsubsection{Smoke yields per puff}

The yields of each compound on a per puff basis are listed in Table 4. The majority of them (16 out of 21) decreased when the circumference of the cigarette changed from $24 \mathrm{~mm}$ to $17 \mathrm{~mm}$, except for formaldehyde, crotonaldehyde and several tobacco-specific nitrosamines. In our previous work (23), we proposed to divide the pyrolysis zone and the combustion zone according to the temperature and heating rates. On account of the temperature at the ignition points, which was usually about $430^{\circ} \mathrm{C}(29)$, the combustion zone was defined as: $T a \geq 430{ }^{\circ} \mathrm{C}, T a \geq T b$ and $d T / d t \geq 0$; the pyrolysis zone was defined as: $200{ }^{\circ} \mathrm{C} \leq T a<430{ }^{\circ} \mathrm{C}$, $T a \geq T b, d T / d t \geq 0$. Points $a$ and $b$ were two infinitesimal points with the same axial direction inside the cigarette combustion coal, and point $a$ was near the lighting end of the tobacco rod. We followed this approach here, and the calculated average volume of the pyrolysis zone and the combustion zone showed an increase when the cigarette circumference became larger (Table 5). It seems that the decrease of the majority of the smoke chemicals can be attributed to the smaller pyrolysis and combustion zones where the smoke formation took place.

\subsubsection{Smoke yields per NFDPM}

To further explain the smoke chemistry differences, the yields of the chemical compounds were represented per weight of NFDPM, as shown in Table 6 . The change ratio defined as the changes caused by the cigarette diameter (17 vs. $24 \mathrm{~mm}$ ) was from $9.02 \%$ to $30.2 \%$. The ratio of $\mathrm{B}[a] \mathrm{P}$ to NFDPM was the most noticeable (30.2\%). The ratios of $\mathrm{CO}, \mathrm{NH}_{3}$, butyraldehyde, acetaldehyde, acetone, 2-butanone, phenol and HCN, each in relation to NFDPM, decreased by about $27.31 \%, 22.23 \%, 25.88 \%, 21.15 \%$,
Table 4. Yields of chemical compounds in mainstream cigarette smoke per puff.

\begin{tabular}{l|r|r|r}
\hline Compound & $24 \mathrm{~mm}$ & $20 \mathrm{~mm}$ & $17 \mathrm{~mm}$ \\
\hline TPM $(\mathrm{mg})$ & 2.25 & 2.30 & 2.17 \\
$\mathrm{H}_{2} \mathrm{O}(\mathrm{mg})$ & 0.39 & 0.41 & 0.42 \\
Nicotine $(\mathrm{mg})$ & 0.16 & 0.16 & 0.14 \\
NFDPM $(\mathrm{mg})$ & 1.71 & 1.73 & 1.61 \\
$\mathrm{CO}(\mathrm{mg})$ & 2.06 & 1.58 & 1.41 \\
$\mathrm{~B}[\mathrm{a}] \mathrm{P}(\mathrm{ng})$ & 1.49 & 1.41 & 0.98 \\
$\mathrm{HCN}(\mu \mathrm{g})$ & 16.57 & 15.31 & 14.19 \\
Ammonia $(\mu \mathrm{g})$ & 1.21 & 1.12 & 0.88 \\
Phenol $(\mu \mathrm{g})$ & 2.98 & 2.32 & 2.49 \\
Crotonaldehyde $(\mu \mathrm{g})$ & 2.85 & 3.06 & 3.13 \\
NNK $(\mathrm{ng})$ & 0.78 & 0.78 & 0.85 \\
NNN $(\mathrm{ng})$ & 0.42 & 0.39 & 0.39 \\
NAT $(\mathrm{ng})$ & 1.42 & 1.48 & 1.51 \\
NAB $(\mathrm{ng})$ & 0.08 & 0.07 & 0.06 \\
Formaldehyde $(\mu \mathrm{g})$ & 16.15 & 23.7 & 26.46 \\
Acetaldehyde $(\mu \mathrm{g})$ & 95.15 & 81.09 & 70.61 \\
Acetone $(\mu \mathrm{g})$ & 41.21 & 32.98 & 28.71 \\
Acrolein $(\mu \mathrm{g})$ & 13.49 & 14.05 & 12.42 \\
Propionaldehyde $(\mu \mathrm{gg})$ & 7.73 & 6.93 & 6.67 \\
2-Butanone $(\mu \mathrm{g})$ & 9.64 & 8.01 & 6.97 \\
Butyraldehyde $(\mu \mathrm{gg})$ & 4.28 & 3.45 & 2.98 \\
\hline
\end{tabular}

Table 5. Average volume of tobacco consumed. Volume of pyrolysis $\left(V_{p}\right)$ and combustion $\left(V_{c}\right)$.

\begin{tabular}{l|c|c}
\hline Sample circumference $(\mathrm{mm})$ & $V_{p}\left(\mathrm{~mm}^{3}\right)$ & $V_{c}\left(\mathrm{~mm}^{3}\right)$ \\
\hline 24 & 109.4 & 133.2 \\
20 & 95.9 & 94.2 \\
17 & 48.3 & 80.0 \\
\hline
\end{tabular}


Table 6. Yields of chemical compounds normalized by weight of NFPDM in mainstream smoke.

\begin{tabular}{|c|c|c|c|c|}
\hline Compound & $24 \mathrm{~mm}$ & $20 \mathrm{~mm}$ & $17 \mathrm{~mm}$ & Change ratio $(\%)^{\star}$ \\
\hline TPM (mg / mg) & 1.32 & 1.33 & 1.35 & 2.28 \\
\hline $\mathrm{H}_{2} \mathrm{O}(\mathrm{mg} / \mathrm{mg})$ & 0.23 & 0.24 & 0.26 & 16.49 \\
\hline Nicotine (mg / mg) & 0.09 & 0.09 & 0.09 & -7.47 \\
\hline $\mathrm{CO}(\mathrm{mg} / \mathrm{mg})$ & 1.21 & 0.92 & 0.88 & -27.31 \\
\hline $\mathrm{B}[\mathrm{a}] \mathrm{P}$ (ng / mg) & 0.87 & 0.82 & 0.61 & -30.23 \\
\hline Ammonia ( $\mu \mathrm{g} / \mathrm{mg}$ ) & 0.71 & 0.65 & 0.55 & -22.26 \\
\hline Phenol $(\mu \mathrm{g} / \mathrm{mg})$ & 1.75 & 1.34 & 1.55 & -11.41 \\
\hline Crotonaldehyde ( $\mu \mathrm{g} / \mathrm{mg})$ & 1.67 & 1.77 & 1.95 & 16.47 \\
\hline NNK (ng / mg) & 0.46 & 0.45 & 0.53 & 15.49 \\
\hline $\mathrm{HCN}(\mu \mathrm{g} / \mathrm{mg})$ & 9.71 & 8.86 & 8.83 & -9.02 \\
\hline NNN (ng / mg) & 0.24 & 0.23 & 0.24 & -1.23 \\
\hline NAT (ng / mg) & 0.83 & 0.86 & 0.94 & 12.93 \\
\hline $\mathrm{NAB}(\mathrm{ng} / \mathrm{mg})$ & 0.05 & 0.04 & 0.04 & -20.26 \\
\hline Formaldehyde $(\mu \mathrm{g} / \mathrm{mg})$ & 9.46 & 13.72 & 16.46 & 74.05 \\
\hline Acetaldehyde $(\mu \mathrm{g} / \mathrm{mg})$ & 55.73 & 46.92 & 43.94 & -21.15 \\
\hline Acetone $(\mu \mathrm{g} / \mathrm{mg})$ & 24.14 & 19.08 & 17.87 & -25.97 \\
\hline Acrolein $(\mu \mathrm{g} / \mathrm{mg})$ & 7.90 & 8.13 & 7.73 & -2.14 \\
\hline Propionaldehyde $(\mu \mathrm{g} / \mathrm{mg})$ & 4.53 & 4.01 & 4.15 & -8.25 \\
\hline 2-Butanone $(\mu \mathrm{g} / \mathrm{mg})$ & 5.65 & 4.64 & 4.34 & -23.16 \\
\hline Butyraldehyde $(\mu \mathrm{g} / \mathrm{mg})$ & 2.50 & 1.99 & 1.868 & -25.88 \\
\hline
\end{tabular}

* indicates the difference between $17 \mathrm{~mm}$ and $24 \mathrm{~mm}$ only.

$25.96 \%, 23.16 \%, 11.41 \%$, and $21.15 \%$, respectively, when the cigarette circumference was reduced from $24 \mathrm{~mm}$ to $17 \mathrm{~mm}$. The ratio of formaldehyde to NFDPM increased by $74 \%$ (from $9.46 \mu \mathrm{g} / \mathrm{mg}$ to $16.46 \mu \mathrm{g} / \mathrm{mg}$ ) when the circumference changed from $24 \mathrm{~mm}$ to $17 \mathrm{~mm}$, which agreed with other recent research results (15). Previously, we have shown that the gas flow velocity at the axial center of the cigarette rod at $17 \mathrm{~mm}$ circumference was the highest, introducing more air per weight of tobacco into the combustion process (24). IRWIN (6) showed that, as the level of oxygen rose, the ratio of formaldehyde to NFDPM increased. Therefore, formaldehyde yields are probably related to the amount of tobacco oxidation.

\subsubsection{Smoke yields per weight of tobacco burnt during puffing}

Because the mass of cut tobacco consumed per puff was different for the three cigarette designs (Table 3), the yields of chemical compounds in the mainstream smoke were normalized by yield per weight of tobacco consumed during puffing, for a more objective evaluation of the differences. As shown in Figure 7, the yields of the majority of chemical compounds evaluated per weight of tobacco consumed during puffing were distinctly increased compared to those evaluated on a per-puff basis, such as TPM, NFDPM, CO, nicotine, crotonaldehyde, NNK, HCN, phenol and propionaldehyde. Based on the temperatures and heating rates at positions A, B and C (Figure 5), the cigarettes of $17 \mathrm{~mm}$ circumference displayed a much higher temperature and heating rate during puffs in both the combustion and the pyrolysis zone. The results of this study indicate that temperature and heating rates have a significant effect on smoke generation.

\section{CONCLUSIONS}

A systematic investigation was performed using cigarettes with three different circumferences $(24 \mathrm{~mm}, 20 \mathrm{~mm}$, and $17 \mathrm{~mm}$ ). A comparison was made between their combustion characteristics defined by a range of temperatures and coal volume parameters. The cigarettes of $17 \mathrm{~mm}$ circumference showed higher temperatures but a lower combustion coal volume. The maximum instantaneous burn rate was distinctly different for the three test cigarettes, from $1.84 \mathrm{~mm} / \mathrm{s}$ to $2.48 \mathrm{~mm} / \mathrm{s}$, when the circumference was reduced. The average burn rate $(\mathrm{mm} / \mathrm{s})$ increased, which was contrary to the amount of tobacco consumed per puff. As the circumference changed from $24 \mathrm{~mm}$ to $17 \mathrm{~mm}$ under machine-smoking conditions, the majority of the mainstream smoke compounds (16 of 21) decreased. Furthermore nine out of twenty compounds showed a declining trend, which was normalized by yields of per-unit weight of NFDPM, while all chemicals analyzed in the mainstream smoke by per-weight-of-tobacco-consumed-during-puffing displayed a positive trend.

\section{REFERENCES}

1. McAdam, K., A. Eldridge, M. Fearon, C. Liu, A. Manson, J. Murphy, and A. Porter: Influence of Cigarette Circumference on Smoke Chemistry, Biological Activity, and Smoking Behaviour; Regul. Toxicol. Pharmacol. 82 (2016) 111-126.

DOI: $10.1016 /$ j.yrtph.2016.09.010

2. Lugton, W.G.D.: Cigarette Parameters: The Effect of Altering the Circumference; BAT Report No RD.834R. Available at: http://industrydocuments.library.ucsf. edu/tobacco/docs /hnby0193 (accessed February 2019). 


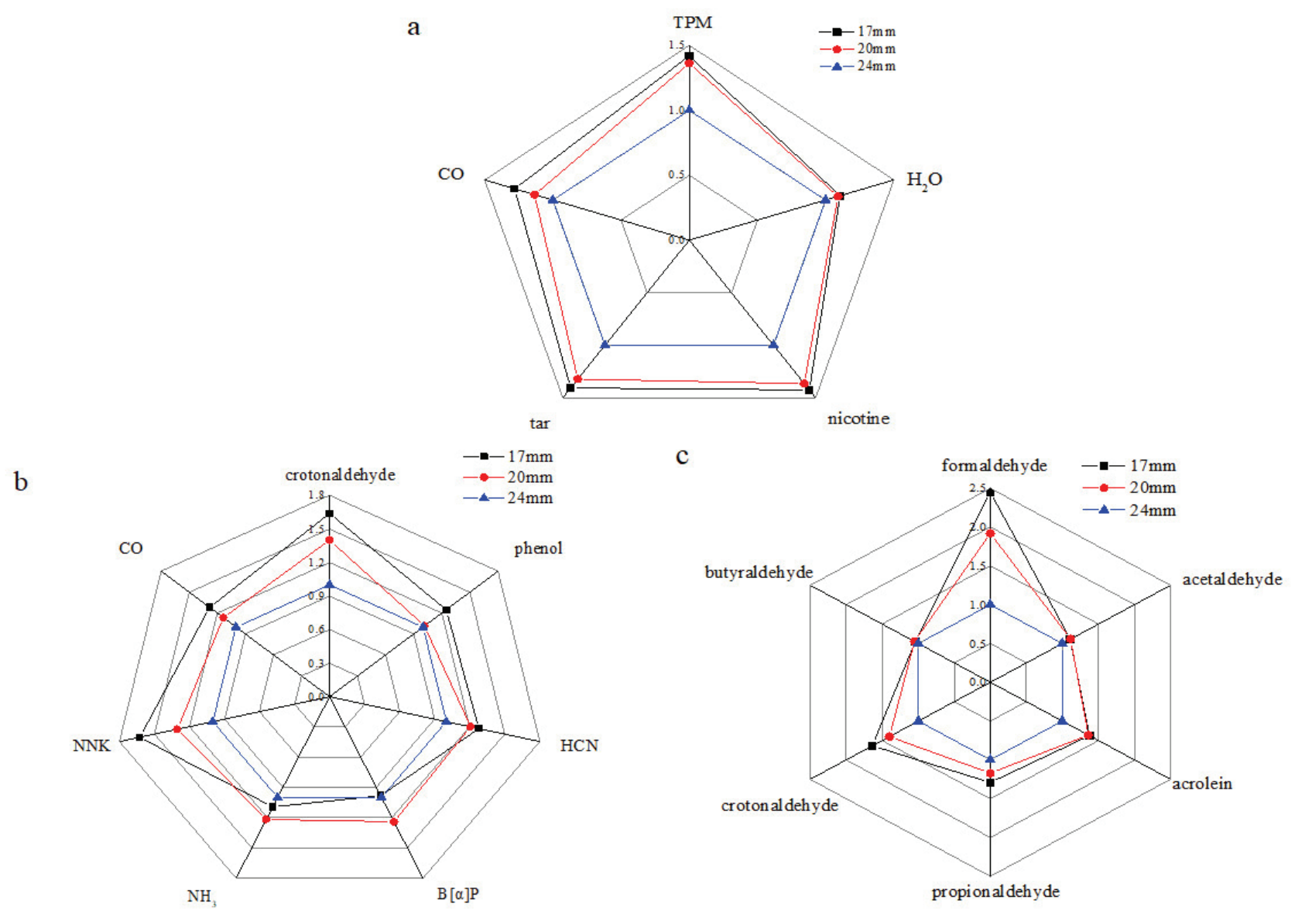

Figure 7. Yields of (a) main smoke chemicals, (b) seven toxicants, and (c) additional toxicants in mainstream smoke. The yields were determined per weight of tobacco consumed during puffing for three cigarettes of different circumferences.

3. Perfetti, P.F., D.E. Townsend, and J.N. Taylor: The Effect of Circumference on Cigarette Burn Rates and Deliveries; RJRT Report R\&DM No 75. Project No 7608, 1983. Available at: http://industrydocuments. library.ucsf.edu/tobacco/docs/qjhg0082 (accessed February 2019).

4. Schneider, W. and A. Schlüter: A Semi-Empirical Model for Simulating the Effect of Design Components on Smoke Deliveries; BAT Forschung Entwicklung und Produktion, 1987. Available at: https://industry documents.library.ucsf.edu/tobacco/docs/\#id=msfl0138 (accessed February 2019).

5. Norman, A.: Cigarette Design and Materials; Chapter 11B in: Tobacco: Production, Chemistry and Technology, edited by D.L. Davis and M.T. Nielsen, Blackwell Science, Oxford, UK, 1999, 353-387.

6. Irwin, W.D.E.: The Effect of Circumference on Mainstream Deliveries and Composition: Progress Report 2; BAT Report No RD. 2135, BAT UK, February 22, 1989. Available at: https://www.industrydocuments. library.ucsf.edu/tobacco/docs/\#id=lnvv0205 (accessed February 2019).

7. Liu, C., Y. DeGrandpré, A. Porter, A. Griffiths, K.G. McAdam, R. Voisine, F. Côté, and C.J. Proctor: The Use of a Novel Tobacco Treatment Process to Reduce Toxicant Yields in Cigarette Smoke; Food Chem. Toxicol. 49 (2011) 1904-1917.

DOI: $10.1016 /$ j.fct.2011.02.015
8. McAdam, K.G., E.O. Gregg, C. Liu, D.J. Dittrich, M.G. Duke, and C.J. Proctor: The Use of a Novel TobaccoSubstitute Sheet and Smoke Dilution to Reduce Toxicant Yields in Cigarette Smoke; Food Chem. Toxicol. 49 (2011) 1684-1696. DOI: 10.1016/j.fct.2011.04.002

9. McAdam, K.G., E.O. Gregg, M. Bevan, D.J. Dittrich, S. Hemsley, C. Liu, and C.J. Proctor: Design and Chemical Evaluation of Reduced Machine-Yield Cigarettes; Regul. Toxicol. Pharmacol. 62 (2012) 138-150. DOI: 10.1016/j.yrtph.2011.11.007

10. Dittrich, D.J., R.T. Fiebelkorn, M.J. Bevan, D. Rushforth, J.J. Murphy, M. Ashley, K.G. McAdam, C. Liu, and C.J. Proctor: Approaches for the Design of Reduced Toxicant Emission Cigarettes; SpringerPlus 3 (2014) 374. DOI: 10.1186/2193-1801-3-374

11. Baker, R.R.: Product Formation Mechanisms Inside a Burning Cigarette; Prog. Energy Combust. Sci. 7 (1981) 135-153. DOI: 10.1016/0360-1285(81)90008-3

12. DeBardeleben, M.A., W.E. Claflin, and W.F. Gannon: Role of Cigarette Physical Characteristics on Smoke Composition; Rec. Adv. Tob. Sci. 4 (1978) 85-111.

13. Yamamoto, T., U. Anzai, and T. Okada: Effect of Cigarette Circumference on Weight Loss During Puffs and Total Delivery of Tar and Nicotine; Beitr. Tabakforsch. Int. 12 (1984) 259-269. DOI: 10.2478/cttr-2013-0547

14. Yamamoto, T., Y. Suga, C. Tokura, T. Toda, and T. Okada: Effect of Cigarette Circumference on Formation Rates of Various Components in Mainstream Smoke; 
Beitr. Tabakforsch. Int. 13 (1985) 81-87.

DOI: $10.2478 /$ cttr-2013-0559

15. Siu, M., N. Mladjenovic, and E. Soo: The Analysis of Mainstream Smoke Emissions of Canadian 'Super Slim' Cigarettes; Tob. Control. 22 (2013) e10. DOI: $10.1136 /$ tobaccocontrol-2012-050450

16. Laszlo, T.S. and F.M. Watson III: A Scanning Infrared Technique for Cigarette Coal Peak Temperature Measurements; Beitr. Tabakforsch. 7 (1974) 269-275. DOI: $10.2478 / \mathrm{cttr}-2013-0341$

17. Baker, R.R.: Temperature Distribution Inside a Burning Cigarette; Nature 247 (1974) 405-406.

DOI: $10.1038 / 247405 \mathrm{a} 0$

18. Baker, R.R.: Temperature Variation Within a Cigarette Combustion Coal During the Smoking Cycle; High Temp. Sci. 7 (1975) 236-247.

19. Muramatsu, M.: Studies on the Transport Phenomena in Naturally Smoldering Cigarettes; Kenkyu Hokoku, Scientific Papers of the Central Research Institute, Japan Tobacco \& Salt Public Corporation, 1981.

20. Li, B., H.R. Pang, L.C. Zhao, B. Wang, C. Liu, K.G. McAdam, and D.S. Luo: Quantifying Gas-Phase Temperature Inside a Burning Cigarette; Ind. Eng. Chem. Res. 53 (2014) 7810-7820. DOI: 10.1021/ie5009822

21. Li, B., L.C. Zhao, C.F. Yu, C. Liu, Y. Jing, H.R. Pang, B. Wang, and K.G. McAdam: Effect of Machine Smoking Intensity and Filter Ventilation Level on GasPhase Temperature Distribution Inside a Burning Cigarette; Beitr. Tabakforsch. Int. 26 (2014) 191-203. DOI: $10.1515 / \mathrm{cttr}-2015-0007$

22. Li, B., L.C. Zhao, L. Wang, C. Liu, K.G. McAdam, and B. Wang: Gas-Phase Pressure and Flow Velocity Fields Inside a Burning Cigarette During a Puff; Thermochim. Acta 623 (2016) 22-28. DOI: 10.1016/j.tca.2015.11.006

23. Cui, X.M., C.F. Yu, H.J. Li, L. Wang, L.C. Zhao, and B. Li: Characterization of Instantaneous Burning Rate and Analysis of Regional Characters in Burning Cone Based on Cigarette Temperature Measurement Technology; Tob. Sci. Technol. 50 (2017) 73-79. DOI: $10.16135 / \mathrm{j}$.issn1002-0861.2016.0362

24. Cui, X.M.: The Influence of Tobacco Structure on the Combustion State of Cigarette; Thesis, Available at: http://g.wanfangdata.com.cn/details/detail.do?_type= degree\&id=D01199943\# (accessed February 2019).

25. Resnik, F.E., W.G. Houck, W.A. Geiszler, and J.E. Wickham: Factors Affecting Static Burning Rate; Tob. Sci. XXI (1977) 103-107. Available at: https:/www. coresta.org/sites/default/files/abstracts/Tobacco Science_1977_XXI_p._103-7_ISSN.0082-4623.pdf (accessed August 2019)

26. Baker, R.R.: A Review of Methods of Altering the Burning Characteristics of Cigarettes; BAT Report No. RD 1012-R, June 4, 1973. Available at: http://industry documents.library.ucsf.edu/tobacco/docs/npdp0205 (accessed August 2019)
27. Irwin, W.D.E.: The Effect of Circumference on Mainstream Deliveries and Composition; Progress Report. BAT Report No RD. 2112, March, 30, 1988. Available at: http://industrydocuments.library.ucsf.edu/tobacco/ docs/qhng0207 (accessed February 2019).

28. Rodgman, A. and T.A. Perfetti: The Chemical Components of Tobacco and Tobacco Smoke; CRC Press, Boca Raton, FL, USA, 2013.

29. Zhou, S.Y.: Effects of Redrying and Drying Process on Pyrolysis and Combustion Characteristics of Tobacco Biomass; Thesis, Shanghai, East China University of Science and Technology, 2015. Available at: http://g. wanfangdata.com.cn/details/detail.do?_type=degree\& id=Y2970618 (accessed August 2019)

30. International Organisation for Standardization (ISO): ISO 4387:2000 - Cigarettes - Determination of Total and Nicotine-Free Dry Particulate Matter Using a Rroutine Analytical Smoking Machine; ISO, Geneva, Switzerland, 2000.

31. International Organisation for Standardization (ISO): ISO 10315:2000 - Cigarettes - Determination of Nicotine in Smoke Condensates - Gas-Chromatographic Method; ISO Geneva, Switzerland, 2000.

32. International Organisation for Standardization (ISO): ISO 10362-2:2013 - Cigarettes - Determination of Water in Smoke Condensates - Part 2: Karl Fischer Method; ISO Geneva, Switzerland, 2013.

33. International Organisation for Standardization (ISO): ISO ISO 8454:1995 - Cigarettes - Determination of Carbon Monoxide in the Vapour Phase of Cigarette Smoke - NDIR method; ISO Geneva, Switzerland, 1995.

34. International Organisation for Standardization (ISO): ISO 3308:2012 - Routine Analytical CigaretteSmoking Machine - Definitions and Standard Conditions, ISO, Geneva, Switzerland, 2012.

Corresponding author:

Bin Li, Ph.D.

Zhengzhou Tobacco Research Institute of CNTC

Zhengzhou 450001, Henan

China

E-mail: ztrilibin@163.com 